\title{
Physico-Chemical Composition and Antimicrobial Protein Content of Early Lactation Donkey Milk
}

\author{
Maria Aspri $^{\mathrm{a}}$, Kallis Souroullas ${ }^{\mathrm{a}}$, Christina Ioannou ${ }^{\mathrm{a}}$, And Photis Papademas ${ }^{\mathrm{a}^{*}}$ \\ ${ }^{\text {a }}$ Department of Agricultural Sciences, Biotechnology and Food Science, Cyprus University of Technology, \\ Limassol, Cyprus \\ ${ }^{*}$ Corresponding author \\ photis.papademas@cut.ac.cy \\ TEL: +35725002581 \\ FAX: +35725002562
}

Received: 12 May 2018; Published online: 18 April 2019

\begin{abstract}
The influence of early lactation on chemical composition and the concentration of antimicrobial proteins of donkey's milk produced in Cyprus were investigated. Milk samples from 10 female donkeys in their first season of lactation were collected at 7, 15 and $30 \mathrm{~d}$ postpartum. The average contents of donkey milk gross composition were $1.40 \%$ protein, $0.16 \%$ fat and $8.74 \%$ total solids. Results showed that lactation had a significant negative effect on protein concentration, while total solid concentration showed an increased followed by a decrease. Composition of antimicrobial proteins also showed a significant decreased during lactation period except from lactoferrin which showed an increase. On the other hand, throughout the lactation, $\mathrm{pH}$ and fat were constant.
\end{abstract}

Keywords: Donkey milk; Antimicrobial proteins; Immunoglobulin-A; Lactation

\section{Introduction}

Milks from non traditional animal species (i.e., donkey, camel, and buffalo) are gaining interest due to the fact that they are considered suitable to supplement the needs of special population groups such as infants and elderly. Donkey milk has been studied less compared to that of ruminant milks, but in recent years interest in donkey's milk production and commercialization have significantly increased. This increase in interest is due to its unique nutritional and physicochemical characteristics as well as its functional properties such as antimicrobial, immunomodulatory, anti-inflammatory, and antihypertensive properties (Aspri, Economou, \& Papademas, 2017; Brumini et al., 2013; Jirillo \& Magrone, 2014; Mao et al., 2009; Zhang, Zhao, Jiang, Dong, \& Ren, 2008).

Copyright (C)2019 ISEKI-Food Association (IFA)
The nutritional composition of donkey milk is very similar to that of human milk and it has been reported to be an adequate replacement for children with cow milk protein allergy, mainly due to its tolerability, nutritional contents and good taste (Aspri et al., 2017; Monti et al., 2012). Donkey milk is characterized by low fat and protein content and high lactose content. It is also characterized by low casein content and a particularly high whey protein concentration, rich in lysozyme which is around 6000 times more than lysozyme content of bovine milk (Guo et al., 2007; Salimei et al., 2004).

Previous studies have shown that the strong antimicrobial activity of donkey milk arise from its high concentrations of antimicrobial agents such as lysozyme and lactoferrin (Tidona et al., 2011; Vincenzetti et al., 2008). Lysozyme is the main protein in donkey's milk that plays an impor-

10.7455/ijfs/8.1.2019.a6 
tant role of fighting infections in breastfeeding infants, while lactoferrin is the second antimicrobial protein in donkey milk (Uniacke-Lowe, Huppertz, \& Fox, 2010). In addition, these two antimicrobial proteins work synergistically with other proteins such as lactoperoxidase and immunoglobulins (Polidori \& Vincenzetti, 2010). The high content of these antimicrobial proteins are considered to be the reason for the low microbial counts in donkey milk (Chiavari, Coloretti, Nanni, Sorrentino, \& Grazia, 2005; Salimei et al., 2004; Sarić et al., 2012; Vincenzetti et al., 2008). As some donkey milk producers are marketing "early lactation milk" the aim of this research was to study the influence of early lactation stage on some physicochemical parameters of donkey milk (TS, protein, fat and $\mathrm{pH}$ ) and also on the concentration of antimicrobial proteins of donkey milk.

\section{Materials and Methods}

\subsection{Animals and sampling procedure}

This study was carried out at "Golden donkey's farm" located in Skarinou, Cyprus. The farm had three breeds of donkeys (Asia, Cyprus and Israel) and their crosses. Raw milk samples were obtained by hand milked of 10 female donkeys, after parturition on $1^{\text {st }}, 15^{\text {th }}$ and $30^{t h}$ day of lactation, always at the same time of the day. The animals were maintained within the same conditions, and receiving the same feeding level and composition. Their diet was composed of hay, wheat and silage. The milk samples of an average volume of $100 \mathrm{~mL}$ were collected in standard containers, and transported same day to the laboratory, and kept at $4^{\circ} \mathrm{C}$ for further analysis.

\subsection{Physicochemical analysis}

\section{Determination of $\mathrm{pH}$}

The $\mathrm{pH}$ of the donkey milk samples was determined by potentiometry. The $\mathrm{pH}$ meter glass probe was first calibrated using standard buffers at $\mathrm{pH} 4$ and 7 before being used to measure the sample pH. Sample $\mathrm{pH}$ was measured by submerging the tip of the probe into the sample for 1-2 min until a stable reading was registered on the $\mathrm{pH}$ meter scale. Measurements were done in triplicates and average values were reported.

\section{Protein content}

The protein content of milk samples was determined using the Bradford Protein assay (Bradford, 1976). Bovine serum albumin (BSA) was prepared for standard curve using the following concentrations, $50 \mu \mathrm{g} / \mathrm{ml}$ to $300 \mu \mathrm{g} / \mathrm{ml}$. After incubated for 5 minutes at room temperature, absorbance measurements were determined spectrophotometrically (Infinite PRO 200, Tecan, Switzerland), at $595 \mathrm{~nm}$. The Bradford reagent was used as a blank. Measurements were done in triplicates and average values were reported.

\section{Fat content}

Milk fat content was determined by a butyrometric method according to Gerber (IDF ISO 488, 2008). Milk samples $(11 \mathrm{ml})$ were mixed with sulfuric acid $(10 \mathrm{ml})$ and $1 \mathrm{ml}$ of isoamyl alcohol in butyrometer and closed with rubber cork. The mixture was mixed and placed in a water bath at $65^{\circ} \mathrm{C}$. The sample was centrifuged in a Gerber centrifuge for $5 \mathrm{~min}$ at $1000 \mathrm{rpm}$ and the butyrometer was placed back into the water bath for another $5 \mathrm{~min}$. The fat content is expressed as a percentage on the butyrometer. Measurements were done in triplicates and average values were reported.

\section{Total Solids Content}

Total solids were determined by the oven method in accordance with ISO 6731 (IDF standard 21, 2010a). 2g of fresh donkey milk samples were transferred to a pre-weighed round flat bottom aluminum dish. Then, the dishes were transferred to a hot air oven at $102{ }^{\circ} \mathrm{C}$ for 2 hours. Then the dish was transferred to a desiccator for 30 min to cool down and weighted. Total solids content was calculated by the following formula:

$$
\text { Total solids }(\%)=\frac{m_{2}-m_{0}}{m_{1}-m_{0}} \times 100
$$


where $m_{0}$ is the mass $(\mathrm{g})$ of the dish, $m_{1}$ is the mass $(\mathrm{g})$ of the dish and the test portion and $m_{2}$ is the mass $(\mathrm{g})$ of the dish and the dried test portion. Measurements were done in triplicates and average values were reported.

\subsection{Antimicrobial proteins and $\operatorname{Ig} \mathrm{A}$}

\section{Lysozyme content of donkey milk}

Lysozyme was quantified according to a sensitive fluorescence-based method using EnzChek ${ }^{\circledR}$ kit (Life Technologies, Carlsbad, CA, USA). The assay is based on the assessment of the lytic activity of lysozyme in the cell walls of Micrococcus lysodeikticus which have been labeled with the fluorescent dye fluorescein. The test was performed according to the manufacturer's instructions and the absorbance was determined spectrophotometrically (Infinite PRO 200, Tecan, Switzerland), at $497 \mathrm{~nm}$ and $518 \mathrm{~nm}$. All samples were analyzed in triplicate.

\section{Lactoferrin content of donkey milk}

Quantitative determination of LF in the skim milk samples was performed using a commercial ELISA kit, the Bovine Lactoferrin ELISA Quantification Kit (Bethyl Laboratories, Montgomery, TX). The procedures were performed according to manufacturer's instructions. A standard curve was prepared using the supplied lactoferrin standard diluted to concentrations of 31.2 $\mu \mathrm{g} / \mathrm{ml}, 62.5 \mu \mathrm{g} / \mathrm{ml}, 125 \mu \mathrm{g} / \mathrm{ml}, 250 \mu \mathrm{g} / \mathrm{ml}, 500$ $\mu \mathrm{g} / \mathrm{ml} \mathrm{kal} 1000 \mu \mathrm{g} / \mathrm{ml}$ using the sample diluent buffer (50 $185 \mathrm{mM}$ Tris, $0.14 \mathrm{M} \mathrm{NaCl}, 1 \%$ bovine serum albumin, $0.05 \%$ Tween 20, pH 8.0). The final absorbance of the samples and the standards was measured at $450 \mathrm{~nm}$, using an ELISA plate-reader (Infinite F200; Tecan, Mannedorf, Switzerland), and the concentration of lactoferrin calculated by extrapolating from a standard curve. All samples were analysed in triplicate.

\section{Immunoglobulin A content of donkey milk}

Total IgA in milk was determined by using Horse IgA ELISA Quantitation Kit (Bethyl Labora- tories Inc., Montgomery, TX, USA), according to the manufacturers' instructions. A standard curve was prepared using the supplied lactoferrin standard diluted to concentrations of $1000 \mathrm{~nm} / \mathrm{ml}, 500 \mathrm{~nm} / \mathrm{ml}, 250 \mathrm{~nm} / \mathrm{ml}, 125$ $\mathrm{nm} / \mathrm{ml}, 62,5 \mathrm{~nm} / \mathrm{ml}, 31.25 \mathrm{~nm} / \mathrm{ml}, 15.6 \mathrm{~nm} / \mathrm{ml}$, $0 \mathrm{~nm} / \mathrm{ml}$ using the sample diluent buffer. The final absorbance of the samples and the standards was measured at $450 \mathrm{~nm}$, using an ELISA plate-reader (Infinite F200; Tecan, Mannedorf, Switzerland), and the concentration of IgA calculated by extrapolating from a standard curve. All samples were analyzed in triplicate.

\subsection{Statistical Analysis}

All experiments were carried out in triplicates. The data are expressed as the mean \pm standard deviation (SD). Statistical analysis was performed using SPSS version 17.0 (SPSS Inc., Chicago, IL, USA). The data were subjected to one-way analysis of variance (ANOVA) to determine the differences of samples. Significant differences were compared by Tuckey test on the level of $\mathrm{P}<0.05$.

\section{$3 \quad$ Results and Discussions}

\subsection{Physicochemical analysis}

The changes in the physico-chemical parameters and composition (protein, fat, pH, TS) of donkey milk during the early lactation period (30 days) are presented in Table 1.

The $\mathrm{pH}$ value of donkey milk, ranging from 7.03 to 7.06 , did not vary significantly throughout the lactation period (30 days), which was consistent with the findings of Salimei et al. (2004). According to the literature the $\mathrm{pH}$ of donkey milk after milking is $7.19 \pm 0.10$ (Curadi, Giampietro, Lucenti, \& M., 2001). This suggests that the $\mathrm{pH}$ value was not influenced by breed or stage of lactation (Chiavari et al., 2005; Guo et al., 2007; Malacarne, Martuzzi, Summer, \& Mariani, 2002; Polidori, Beghelli, Mariani, \& Vincenzetti, 2009). The average $\mathrm{pH}$ value $(7.03 \pm 0.02)$ of donkey milk was higher than that of cow milk which is in the range of 6.60 to 6.80. According to Salimei et al. (2004), this may be due to the lower casein (CN)

IJFS | April 2019 | Volume 8 | pages 68-75 
Early Lactation Donkey's Milk Characteristics $\mid 71$

Table 1: Chemical composition of donkey milk at different stages during the lactation period

\begin{tabular}{|c|c|c|c|c|c|c|c|c|c|}
\hline & \multicolumn{3}{|c|}{ Day 7} & \multicolumn{3}{|c|}{ Day 15} & \multicolumn{3}{|c|}{ Day 30} \\
\hline & Mean & Min & Max & Mean & Min & Max & Mean & Min & $\operatorname{Max}$ \\
\hline $\begin{array}{l}\text { Protein Content } \\
(\mathrm{g} / 100 \mathrm{ml})\end{array}$ & $1.55 \pm 0.41^{b}$ & 1.02 & 2.19 & $1.75 \pm 0.38^{c}$ & 1.30 & 2.64 & $0.90 \pm 0.21^{a}$ & 1.02 & 1.94 \\
\hline Fat $(\%)$ & $0.15 \pm 0.08^{b}$ & 0.05 & 0.30 & $0.18 \pm 0.22^{c}$ & 0.05 & 0.80 & $0.14 \pm 0.07^{a}$ & 0.05 & 0.30 \\
\hline TS (\%) & $8.73 \pm 0.57^{a}$ & 8.13 & 10.02 & $9.10 \pm 0.40^{b}$ & 8.42 & 9.69 & $8.40 \pm 0.40^{a}$ & 8.29 & 9.22 \\
\hline pH & $7.03 \pm 0.13^{a}$ & 6.83 & 7.27 & $7.01 \pm 0.11^{a}$ & 6.81 & 7.19 & $7.06 \pm 0.07^{a}$ & 6.98 & 7.21 \\
\hline
\end{tabular}

Values are means \pm standard deviation; values within the same row followed by different superscript letters significantly differ $(p<0.05)$.

TS $=$ Total Solid

and phosphate contents in donkey milk than in cow milk (Salimei et al., 2004). The phosphate content of cow milk is $1000 \mathrm{mg} / \mathrm{L}$, while the phosphate content of donkey milk is very low, 638, 42 mg/L (Fantuz et al., 2012).

The total protein content of donkey milk (approximately $1.4 \pm 0.29 \%$ ) was similar to that of human milk and much lower than that of cows', goats' or sheep's milk (Guo et al., 2007). The observed average milk protein content $(1.4 \%)$ was lower $(1.72 \%, 1.89 \%)$ than reported by Salimei et al. (2004) and Giosue, Alabiso, Russo, Alicata, and Torrisi (2008). The protein content of donkey milk at 15 days after lactation is statistically significant higher compared to the first day and the $30^{t h}$ day of lactation $(1.75 \pm 0.38,1.55 \pm 0.41$ and $0.90 \pm 0.21$ respectively, $p<0.05)$. The results are consistent with the findings of Salimei et al. (2004), which have reported a falling trend in the protein level of donkey milk during lactation. This may be due to the differential expression of milk protein synthesis genes during the lactation period. The levels of early lactation protein mRNA increased after parturition, they reach the maximum after a few weeks and then they start decreasing (Demmer, Ross, Ginger, Piotte, \& Grigor, 1998).

In contrast to the protein content, the fat content of donkey milk does not show a statistically significant difference between the different sampling days. However, other studies showed a significant variation of donkey milk fat content throughout the lactation period (Cosentino, Paolino, Freschi, \& Calluso, 2012; Martemucci \& D'Alessandro, 2012; Salimei et al., 2004). These differences indicate that fat content could be affected by breed, breeding area and forage, milking technique, and interval between milkings, as also reported by Fox (2003). The average fat content of donkey milk was $0.16 \pm 0,02 \%$, which is consistent with that reported in the literature for donkey's milk (Ivankovic et al., 2009; Salimei et al., 2004).

The total solids content of donkey milk was significantly higher on the $15^{\text {th }}$ day of lactation compared to the $1^{\text {st }}$ and $30^{\text {th }}$ of lactation $(9.14 \pm 0.38,8.73 \pm 0.56$ and $8.35 \pm 0.39$ respectively, $p<0.05)$. The observed average dry matter content $(8.74 \pm 0.25 \%)$ was consistent with the data for dry matter content $(8.84 \%)$ reported by Salimei et al. (2004) and are not affected by breed, lactation stage or milking conditions. The mean dry matter observed in current donkey milk study was of $8.73+0.11 \%$ which is consistent with the values reported in the literature for donkey milk (Chiavari et al., 2005; Guo et al., 2007; Salimei et al., 2004). The total solids content in the donkey milk according to Polidori et al. (2009) can be up to $8.80 \mathrm{~g} / 100 \mathrm{~g}$, which is lower than the solid residue in cow's milk (12.5 - 13.00 $\mathrm{g} / 100 \mathrm{~g})$, sheep (17.5 - $19.5 \mathrm{~g} / 100 \mathrm{~g})$ and human milk (11.70 - $12.90 \mathrm{~g} / 100 \mathrm{~g})$.

\subsection{Antimicrobial Proteins}

The amount of lysozyme, lactoferrin and IgA concentrations $(\mathrm{mg} / \mathrm{ml})$ at different stages of donkey lactation are presented in Table 2. 
$72 \mid$ Aspri et al.

Table 2: Lysozyme, lactoferrin and IgA concentrations in donkey milk at different stages of lactation

\begin{tabular}{lccc}
\hline & Day 7 & Day 15 & Day 30 \\
\hline Lysozyme $(\mathbf{U} / \mathbf{m l})$ & $225.08 \pm 7.05^{b}$ & $224.11 \pm 6,00^{a}$ & $201.94 \pm 10.96^{a}$ \\
Lactoferrin $(\mu \mathbf{g} / \mathbf{m l})$ & $111.03 \pm 41.04^{b}$ & $\mathrm{Nd}$ & $135.08 \pm 27.68^{c}$ \\
$\mathbf{I g A}(\mathbf{n g} / \mathbf{m l})$ & $2674.40 \pm 133.72^{c}$ & $2576.47 \pm 143.04^{a}$ & $2267.32 \pm 145.12^{a}$ \\
\hline Values are means \pm standard deviation; values within the same row followed by different superscript letters significantly \\
differ $(\mathbf{p}<0.05)$. \\
Nd=Not determined
\end{tabular}

\section{Lysozyme}

The EnzChek fluorescence-based assay measures lysozyme activity on Micrococcus lysodeikticus cells, which are labeled to such a degree that the fluorescence is quenched. Lysozyme action can relieve this quenching and the increase in fluorescence that is proportional to lysozyme activity. The mean lysozyme activity value was $217.04 \pm 13.09 \mathrm{U} / \mathrm{ml}$. Our results were in accordance with other studies carried out by Gubić et al. (2014); Guo et al. (2007); Pilla, Dapra, Zecconi, and Piccinini (2010); Sarić et al. (2012); Sarić et al. (2014); Vincenzetti et al. (2011). The lysozyme content at $30^{\text {th }}$ day was significantly lower compared to the lysozyme content at $1^{\text {st }}$ and $15^{\text {th }}$ day of lactation $(201.94 \pm 10.96$, $225.08 \pm 7.05$ and $224.11 \pm 5.99$ respectively, $p<0.05)$.

The high lysozyme content of donkey milk plays an important role in the prevention or reduction of intestine infections in infants and is also responsible for the low bacteria count of donkey milk reported in literature (Salimei et al., 2004). Moreover, the high lysozyme content does not affect the growth or the acidification activity of probiotic strains, making donkey milk a good base for the production of probiotic fermented milk beverages (Chiavari et al., 2005; Coppola et al., 2002). Finally, the high lysozyme activity could explain the low incidences of mastitis in donkeys (Conte et al., 2006). Donkey milk lysozyme belongs to C-type calcium-binding lysozyme and is able to bind calcium ions; this binding leads to more stable complex with an enhanced antimicrobial activity (Wilhelm et al., 2009).

\section{Lactoferrin}

Results of lactoferrin content in donkey milk showed that lactoferrin content at $30^{t h}$ day of lactation was significantly higher compared to the $1^{\text {st }}$ day of lactation $(135.08 \pm 27,68$ and $111.03 \pm 41.04$ respectively, $p<0.05)$, which is in agreement with literature. A study carried out by Gubić et al. (2015) showed that the concentration of lactoferrin is increased over the lactation period. Moreover, according to Adlerova, Bartoskova, and Faldyna (2008), there is an important correlation between lactation and lactoferrin levels. In general, the content of lactoferrin in donkey milk is higher than in ruminant milk, but much lower than in mare and in human milk (Kanyshkova, Buneva, \& Nevinsky, 2001).

Lactoferrin is an iron-binding protein that displays many biological functions such as antioxidant, antiviral, anti-inflammatory, immunomodulatory and anti-carcinogenic activity (Kuwata et al., 1998; Ward, Paz, \& Conneely, 2005). Furthermore, it controls the proper composition of the intestinal microflora by suppressing the growth of pathogenic bacteria while promoting the growth of beneficial bacteria such as Lactobacillus and Bifidobacterium (Madhusudan, Ramachandra, Udaykumar, Nagraj, \& Jagjivan, 2017). Different studies suggest that lactoferrin and lysozyme work synergistically to inhibit the growth of pathogenic bacteria and contribute to donkey milk's strong overall antibacterial activity against both Gram-positive and Gramnegative bacteria (Sarić et al., 2012; Tidona et al., 2011). In fact, Lf can bind different components in the outer membrane, thereby opening "pores" to enhance susceptibility of Gramnegative bacteria to the lysozyme by increas-

IJFS | April 2019 | Volume 8 | pages 68-75 
ing in membrane permeability (Ellison \& Giehl, 1991; Leitch \& Willcox, 1999).

\section{Immunoglobulin-A (IgA)}

The concentration of $\operatorname{IgA}$ of donkey milk was significantly lower at the $30^{\text {th }}$ day of lactation compared to the $1^{\text {st }}$ and $15^{\text {th }}$ day of lactation. $\quad(2267.32 \pm 159.91,2674.47 \pm 178.14$ and $2576.47 \pm 167.34$ respectively, $p<0.05)$. The average value of $\operatorname{IgA}$ was $2.50 \mathrm{~g} / \mathrm{L}$.

Immunoglobulins (Igs) are a defence family of globular proteins with antimicrobial and other protective bioactivities. They play an important role in transferring immunity to the newborn by establishing an optimal microfloral population in the gut of the newborn inactivate bacteria by binding to specific sites on the bacterial surface, while its own immune system is developing (Gapper, Copestake, Otter, \& Indyk, 2007).

\section{Conclusion}

In conclusion, lactation stage affected the gross composition of donkey milk but had no significant effect on $\mathrm{pH}$ and fat content. It can be concluded that the chemical composition of milk in terms of fat, protein, $\mathrm{pH}$, total solid residue, lysozyme, lactoferrin and IgA showed significant differences throughout the different stages of lactation except for fat and $\mathrm{pH}$. However, further research is 1 needed to establish how donkey's nutrition affects the quality of milk; as it is a type of milk of particular interest with unique composition.

\section{Acknowledgements}

The authors wish to thank the Golden Donkeys Farm, Larnaca Cyprus for providing the samples.

\section{References}

Adlerova, L., Bartoskova, A., \& Faldyna, M. (2008). Lactoferrin: A review. Veterinarni Medicina, 53(9), 457-468.
Aspri, M., Economou, N., \& Papademas, P. (2017). Donkey milk: An overview on functionality, technology, and future prospects. Food Reviews International, 33(3), 316333. doi:10.1080/87559129.2016.1175014

Bradford, M. M. (1976). A rapid and sensitive method for the quantitation of microgram quantities of protein utilizing the principle of protein-dye binding. Analytical Biochemistry, 72(1), 248-254. doi:10.1016/ 0003-2697(76)90527-3

Brumini, D., Furlund, C. B., Comi, I., Devold, T. G., Marletta, D., Vegarud, G. E., \& Jonassen, C. M. (2013). Antiviral activity of donkey milk protein fractions on echovirus type 5. International Dairy Journal, 28(2), 109-111. doi:10.1016/j.idairyj. 2012.08.010

Chiavari, C., Coloretti, F., Nanni, M., Sorrentino, E., \& Grazia, L. (2005). Use of donkey's milk for a fermented beverage with lactobacilli. Lait, 85(6), 481-490. doi:10.1051/lait:2005031

Conte, F., Scatassa, M. L., Monsu, G., Lo Verde, V., Finocchiaro, A., \& De Fino, M. (2006). Monitoring of safety and quality of donkey's milk. Food Safety Assurance and Veterinary Public Health: Towards a Riskbased Chain Control, 265-268.

Coppola, R., Salimei, E., Succi, M., Sorrentino, E., Nanni, M., Ranieri, P., ... Grazia, L. (2002). Behaviour of lactobacillus rhamnosus strains in ass's milk. Annals of Microbiology, 52(1), 55-60.

Cosentino, C., Paolino, R., Freschi, P., \& Calluso, A. M. (2012). Short communication: Jenny milk production and qualitative characteristics. Journal of Dairy Science, 95(6), 2910-2915. doi:10.3168/jds.2011-5232

Curadi, M. C., Giampietro, P. G., Lucenti, P., \& M., O. (2001). Use of mare milk in pediatric allergology. In Proceeding of the Associazione Scientifica di Produzione Animale XIV Congress. Firenze 14 (Vol. 2, pp. 647649).

Demmer, J., Ross, I. K., Ginger, M. R., Piotte, C. K., \& Grigor, M. R. (1998). Differential expression of milk protein genes during lactation in the common brushtail possum (trichosurus vulpecula). Journal of Molec- 
74| Aspri et al.

ular Endocrinology, 20(1), 37-44. doi:10 . 1677/jme.0.0200037

Ellison, R. T., \& Giehl, T. J. (1991). Killing of gram-negative bacteria by lactoferrin and lysozyme. Journal of Clinical Investigation, 88(4), 1080-1091. doi:10.1172/JCI115407

Fantuz, F., Ferraro, S., Todini, L., Piloni, R., Mariani, P., \& Salimei, E. (2012). Donkey milk concentration of calcium, phosphorus, potassium, sodium and magnesium. International Dairy Journal, 24 (2), 143-145. International Dairy Federation (IDF) Symposium on Sheep, Goat and other Non-Cow Milk, Athens. doi:10.1016/j.idairyj.2011. 10.013

Fox, P. F. (2003). Dairy processing: Improving quality. CRC Press and Woodhead Publishing Limited. Boca Raton.

Gapper, L. W., Copestake, D. E. J., Otter, D. E., \& Indyk, H. E. (2007). Analysis of bovine immunoglobulin $\mathrm{g}$ in milk, colostrum and dietary supplements: A review. Analytical and Bioanalytical Chemistry, 389(1), 93109. doi:10.1007/s00216-007-1391-z

Giosue, C., Alabiso, M., Russo, G., Alicata, M. L., \& Torrisi, C. (2008). Jennet milk production during the lactation in a sicilian farming system. Animal, 2(10), 14911495. doi:10.1017/S1751731108002231

Gubić, J. M., Šarić, L. Ć., Šarić, B. M., Mandić, A. I., Jovanov, P. T., Plavšić, D. V., \& Okanović, Đ. G. (2014). Microbiological, chemical and sensory properties of domestic donkey's milk from autochthones serbian breed. Journal of Food and Nutrition Research, 2(9), 633-637.

Gubić, J., Milovanović, I., Iličić, M., Tomić, J., Torbica, A., Šarić, L., \& Ilić, N. (2015). Comparison of the protein and fatty acid fraction of balkan donkey and human milk. Mljekarstvo, 65(3), 168-176. doi:10.15567/ mljekarstvo.2015.0303

Guo, H. Y., Pang, K., Zhang, X. Y., Zhao, L., Chen, S. W., Dong, M. L., \& Ren, F. Z. (2007). Composition, physiochemical properties, nitrogen fraction distribution, and amino acid profile of donkey milk. Journal of Dairy Science, 90(4), 1635-1643. doi:10. 3168/jds.2006-600
IDF ISO 488. (2008). International dairy federation, milk - determination of fat content gerber butyrometers, brussels, belgium.

IDF standard 21. (2010a). Milk, cream and evaporated milk- determination of total solids content, brussels, belgium.

Ivankovic, A., Ramljak, J., Stulina, I., Antunac, N., Basic, I., Kelava, N., \& Konjacic, M. (2009). Characteristics of the lactation, chemical composition and milk hygiene quality of the littoral-dinaric ass. $\mathrm{Ml}$ jekarstvo, 59(2), 107-113.

Jirillo, F., \& Magrone, T. (2014). Antiinflammatory and anti-allergic properties of donkey's and goat's milk. Endocrine Metabolic \& Immune Disordersdrug Targets, 14(1), 27-37. doi:10.2174/ 1871530314666140121143747

Kanyshkova, T. G., Buneva, V. N., \& Nevinsky, G. A. (2001). Lactoferrin and its biological functions. Biochemistry (Moscow), 66(1), 1-7. doi:10.1023/A:1002817226110

Kuwata, H., Yip, T. T., Yamauchi, K., Teraguchi, S., Hayasawa, H., Tomita, M., \& Hutchens, T. W. (1998). The survival of ingested lactoferrin in the gastrointestinal tract of adult mice. Biochemical Journal, 334 (2), 321-323. doi:10.1042/bj3340321

Leitch, E. C., \& Willcox, M. D. P. (1999). Elucidation of the antistaphylococcal action of lactoferrin and lysozyme. Journal of Medical Microbiology, 48(9), 867-871. doi:10. 1099/00222615-48-9-867

Madhusudan, N. C., Ramachandra, C. D., Udaykumar, H. D., N. D.a nd Sharnagouda, Nagraj, N. D., \& Jagjivan, R. D. (2017). Composition, characteristics, nutritional value and health benefits of donkey milk-a review. Dairy Science \& Technology, EDP sciences/Springer.

Malacarne, M., Martuzzi, F., Summer, A., \& Mariani, P. (2002). Protein and fat composition of mare's milk: Some nutritional remarks with reference to human and cow's milk. International Dairy Journal, 12(11), 869-877. doi:10 . 1016 / S0958 - 6946(02 ) 00120-6

Mao, X., Gu, J., Sun, Y., Xu, S., Zhang, X., Yang, H., \& Ren, F. (2009). Antiproliferative and anti-tumour effect of ac- 
tive components in donkey milk on a549 human lung cancer cells. International Dairy Journal, 19(11), 703-708. doi:10 . 1016/j.idairyj.2009.05.007

Martemucci, G., \& D'Alessandro, A. G. (2012). Fat content, energy value and fatty acid profile of donkey milk during lactation and implications for human nutrition. Lipids in Health and Disease, 11. doi:10.1186/1476511X-11-113

Monti, G., Viola, S., Baro, C., Cresi, F., Tovo, P. A., Moro, G., .. Bertino, E. (2012). Tolerability of donkeys'milk in 92 highlyproblematic cows' milk allergic children. Journal of Biological Regulators \& Homeostatic Agents, 26, 75-82.

Pilla, R., Dapra, V., Zecconi, A., \& Piccinini, R. (2010). Hygienic and health characteristics of donkey milk during a follow-up study. Journal of Dairy Research, 77(4), 392-397. doi:10.1017/S0022029910000221

Polidori, P., Beghelli, D., Mariani, P., \& Vincenzetti, S. (2009). Donkey milk production: State of the art. Italian Journal of Animal Science, 8(2), 677-683. 18th Congress of the Scientific-Associationof-Animal-Production (ASPA), Palermo. doi:10.4081/ijas.2009.s2.677

Polidori, P., \& Vincenzetti, S. (2010). Differences of protein fractions among fresh, frozen and powdered donkey milk. Recent Patents on Food, Nutrition ES Agriculture, 2(1), 56-60.

Salimei, E., Fantuz, F., Coppola, R., Chiofalo, B., Polidori, P., \& Varisco, G. (2004). Composition and characteristics of ass's milk. Animal Research, 53(1), 67-78. doi:10.1051/ animres:2003049

Sarić, L. Ć., Sarić, B. M., Kravić, S. Ž., Plavšić, D. V., Milovanović, I. L., Gubić, J. M., \& Nedeljković, N. M. (2014). Antibacterial activity of domestic balkan donkey milk toward listeria monocytogenes and staphylococcus aureus. Food and Feed Research, 41(1), 47-54.

Sarić, L. Ć., Sarić, B. M., Mandić, A. I., Torbica, A. M., Tomić, J. M., Cvetković, D. D., \& Okanović, Đ. G. (2012). Antibacterial properties of domestic balkan donkeys' milk. International Dairy Journal,
25(2), 142-146. doi:10.1016/j.idairyj.2012. 03.007

Tidona, F., Sekse, C., Criscione, A., Jacobsen, M., Bordonaro, S., Marletta, D., \& Vegarud, G. E. (2011). Antimicrobial effect of donkeys' milk digested in vitro with human gastrointestinal enzymes. International Dairy Journal, 21 (3), 158-165. doi:10.1016/j.idairyj.2010.10.008

Uniacke-Lowe, T., Huppertz, T., \& Fox, P. F. (2010). Equine milk proteins: Chemistry, structure and nutritional significance. International Dairy Journal, 20(9, SI), 609629. 6th NIZO Dairy Conference, Papendal. doi:10.1016/j.idairyj.2010.02.007

Vincenzetti, S., Polidori, P., Mariani, P., Cammertoni, N., Fantuz, F., \& Vita, A. (2008). Donkey's milk protein fractions characterization. Food Chemistry, 106(2), 640-649. doi:10.1016/j.foodchem.2007.06.026

Vincenzetti, S., Savini, M., Cecchini, C., Micozzi, D., Carpi, F., Vita, A., \& Polidori, P. (2011). Effects of lyophilization and use of probiotics on donkey's milk nutritional characteristics. International Journal of Food Engineering, 7(5). doi:10.2202/ 1556-3758.2032

Ward, P. P., Paz, E., \& Conneely, O. M. (2005). Multifunctional roles of lactoferrin: A critical overview. Cellular and Molecular Life Sciences, 62(22), 2540-2548. doi:10.1007/ s00018-005-5369-8

Wilhelm, K., Darinskas, A., Noppe, W., Duchardt, E., Mok, K. H., Vukojevic, V., ... Morozova-Roche, L. A. (2009). Protein oligomerization induced by oleic acid at the solid-liquid interface-equine lysozyme cytotoxic complexes. Febs Journal, 276(15), 3975-3989. doi:10.1111/j.1742-4658.2009. 07107.x

Zhang, X.-Y., Zhao, L., Jiang, L., Dong, M.-L., \& Ren, F.-Z. (2008). The antimicrobial activity of donkey milk and its microflora changes during storage. Food Control, 19(12), 1191-1195. doi:10.1016/j.foodcont. 2008.01.005

\begin{tabular}{l|l|l|l} 
IJFS & April 2019 & Volume 8 & pages 68-75
\end{tabular} 